\title{
Social Capital Role in Solving Land Degradation in Tulis Watershed
}

\author{
Ari Kusbiantoroa ${ }^{1}$, San Afri Awang ${ }^{1}$, Ahmad Maryudi ${ }^{1}$, Totok Gunawan ${ }^{1}$ \\ ${ }^{1}$ Universitas Gadjah Mada, Indonesia
}

DOI: http://dx.doi.org/10.15294/komunitas.v8i2.5438

Received : 15 March 2016; Accepted: 14 September 2016; Published: 30 September 2016

\begin{abstract}
The research aimed at studying social capital role in land degradation solving of Tulis watershed. The parameters under observation were social capital (trust, norm, and social networking), social-economic condition, and land management in Tulis watershed. The parameters were achieved by using data triangulation principle. The analysis used was Structural Equation Modeling (SEM). The model used five variables, which were social capital (X1), society structure (X2), land using conflict (Y1), land management strategy (Y2), and land degradation (Y3). Perspective of social capital theory could be used to explain the interaction between society socio-cultural behaviors and land degradation of Tulis watershed. The model proved that society structure with effective social capital, low conflict in land using, and good land management strategy afforded to decrease land degradation of Tulis watershed.
\end{abstract}

Keywords: land degradation; model; social capital; watershed; SEM

\section{INTRODUCTION}

Society's cultural and socio-economic aspects are the important factors in defining relation pattern between human and natural resources. Whereas, the management of watershed natural resources sometimes brings conflict. The conflicts are mainly about the balancing of socio-economic and ecology function which are the society life demand and environment preservation (Sadeghi et al. 2008; Brondizio et al. 2009). According to Indrawardana (2012), in completing one's instinctive need, human being will perform any activities by adjusting to their natural environment. Therefore, many cultures adapted from natural condition and environment were created.

Correlation between human and natural environment as the management object is in connection to social aspect of each person in society. Social experts were trying to connect the society's socio-cultural beha- vior and natural resources management system. In further discussion, social capital was appeared as a perspective in study between society and natural resources. The main thesis in this theory is that trust and social norm affected people's social behavior in using the natural resources. In addition, a development of human and nation could be reached effectively, as its mission, by including the cultural angle that is the social capital (Hasbullah 2006; Genskow and Born 2006; Koehler and Koontz 2008; Mandarano et al. 2008; Mandarano 2009). In relation to this definition, social capital was considered important in developing society trough consciously interactions.

The related definition was uttered by Putnam who described social capital as a part of social organization, similar to trust, norm, and networking, which is able to increase the society's efficiency by facilitating the coordinated actions (Putnam 200o). 
Moreover, social capital from the developed trust, the social norm obeyed altogether, and the social networking which is possible for an actor to behave collectively, give contribution to increase the potential capacity of a marginal society to reach their life need and increase their wealth (Handoyo 2013).

From the above explanation, social capital was regarded as an important component in the society to carry out a collectively action. The collectively action was built from the social interaction based on the social capital elements grew in society (Badaruddin 2006; Rathwell and Peterson 2012; Wagner 2008; Fernandez-Gimenez 2008). The social capital elements were named as trust, norm, social networking, and reciprocity among persons in the society (Fukuyama 1995; Grootaert 1998; Leahy and Anderson 2010; Mandarano et al. 2010; Parkes 2010).

Many researches relating to social capital were carried out. One of them was conducted by Handoyo (2013) who concluded that social capital, mainly trust and networking, contributed to traders' wealth which covered not only their basic needs, i. e. food, clothes, and shelter, but also safety and comfort in doing their economic activities. The corresponding research was carried out by Suandi (2014) who assumed that social capital gave the positive impact to a family wellness both directly and indirectly.

Tulis watershed was an area which mainly functioned as water catchment zone. The other function was agriculture area focusing on potato (Solanumtuberosum L.) plantation and other kinds of vegetables. The watershed area used as the intensively agriculture plantation was the upper part. Therefore, the plantation system was considered as the cause of land degradation, especially erosion and sedimentation, which took place in the lower part of the watershed. The changing of land using from forest area into intensively agriculture plantation created high erosion and quickland degradation process. Chomitz and Nelson (2007) said that there is a strong correlation among land degradation, hydrology system, and poverty within a watershed. Degradation process caused by the changing of land using brought about watershed critical condition. This condition caused poverty in society of the watershed.

Theoretical studies that explained the relation between social capital and natural environment were sometimes merely about partial and normative explanation. The explanation concluded on direct relation between social capital and natural resources degradation. On the other hands, factors that influenced or mediated the relation were insignificantly revealed. In further discussion of the theory, the main thesis described that social capital can explain how land degradation happened. Social capital motivated persons of society to behave and act collectively to natural environment so that it affected land degradation.

Pretty and Ward (2001) confirmed that natural resources management and environment preservation are tightly connected with social capital through trust, norm and punishment, reciprocity, and collective action. Similar idea was also uttered by Woolcock (2001) that considered social capital plays an important role in solving the natural resources conflict. Many researchers think that this perspective of social capital is used to estimate the causal relation between social capital and natural resource management (Susilowati 2007; Saputra 2010; Aulia 2011; Setiahadi 2012)

Herewith are several researches related to connection between social capital and natural resources management. First, research conducted by Budiono (2006) explained that the developed social capital of forest-farmers has contributed to maintain the forest preservation. Secondly, Budiono (2010) concluded that social capital affected the farmer association sustainability very much. Meanwhile, research by Setiahadi (2012) found that social capital weakened when there was no restorative effort around which brought deforestation.

Those results show that social capital, as the society's potential power, significantly influenced the natural resources management sustainability. Therefore, the social capital role is considered as an answer to problems of watershed management. 
Referring to the social capital theory in which the elements of trust, norm, and social networking affect society's behavior in natural resources management, the research studied the connectivity between land degradation in Tulis watershed and its social condition. Based on the purpose of the research, hypothesis can be concluded as this. Society structure with strong social capital, lower conflict of interest in land using, and effective strategy in land management were able to decrease land degradation in Tulis watershed.

\section{METHODS}

\section{Study Sites}

Tulis watershed is on the upper part of Serayu River and has 13,648.52 ha area. The topographical area covers mountains which ranged from 600-2000 $\mathrm{m}$ above sea level and various slope from wavy to steep surfaces. Annual rainfall in Tulis watershed is $>3,000$ $\mathrm{mm}$. Types soil in this area are Andosol and Latosol. Most of the area (49\%) was used as horticultural plantation concentrating on potato (Solanumtuberosum L.) and other vegetables (UNDP 2013).

\section{Field Data Collection}

The research population was the society who lived in Tulis watershed. Meanwhile, the research sample was the society who involved in farmer association around the watershed. Sampling was done to 6 farmer associations with 50 respondents from each association.

The research data include primary data and secondary data. Primary data were gained directly from respondents, which were (1) Tulis watershed society's social capital, i. e. trust, norm, and social networking developed in the society, (2) society structure, containing social condition, economy, and culture, (3) conflicts that might arise in natural resources using, and (4) land management system conducted by society along with is effects.

Secondary data was completed by document study and data collecting from village and sub district offices, Forestry and Agricultural Service of Wonosobo Regency,
Forestry and Agricultural Service of Banjarnegara Regency, Agency for Regional Development of Banjarnegara Regency, Managing Board of Serayu Opak Progo Watershed, and other related institutions. The secondary data were including: (1) society's social, economic, and cultural conditions, (2) land using system in Tulis watershed, and (3) biophysical condition of watershed, containing rainfall, surface flows, erosion level, and sedimentation.

Further, field data were collected by data triangulation principle using observation, survey (interview, Focused Group Discussion (FGD), questioner), and document study.

\section{Data Analysis}

Analysis used in the research was Structural Equation Modeling (SEM). SEM analysis was chosen in the research because there was latent variable (indirectly-observed variable) so that between variable, which explained causal relation between indirectlyvariables, was necessary. SEM analysis was also assisted by Lisrel 8.8 software completed with analytical tools.

There were five variables formulated in the model, which were social capital ( $\left.\mathrm{Xl}_{1}\right)$, society structure $\left(\mathrm{X}_{2}\right)$, conflict of interest in land using $\left(\mathrm{Y}_{1}\right)$, land management strategy $\left(\mathrm{Y}_{2}\right)$, and land degradation $\left(\mathrm{Y}_{3}\right)$. The variables were measured using indicators. They turned into statements classified by measurement scale. To simplify, a point was given to each indicator, such as $1=$ never $(\mathrm{N}), 2=\operatorname{seldom}(\mathrm{S}), 3=$ sometimes $(\mathrm{ST}), 4=$ often $(\mathrm{O})$, and $5=$ always $(\mathrm{A})$.

At this point, indicators of each variable were explained further. First variable, social capital (SC), included indicators: trust (TR), norm (NR), and social networking (SN). Second variable, society structure (SS), included: resource-potency of a farmer ( $\left.\mathrm{SS}_{1}\right)$, receptivity of information and technology related to land using ( $\mathrm{SS}_{2}$ ), and society's behaviors related to activities in land management $\left(\mathrm{SS}_{3}\right)$. Third variable, conflict of interest in land using (LUC), included: disobedience to norm and society's rule in land management ( $\left.\mathrm{LUC}_{1}\right)$, disobe- 
dience to norm and society's rule in water management ( $\mathrm{LUC}_{2}$ ), and farmers conflict frequency in land using activity $\left(\mathrm{LUC}_{3}\right)$. Fourth variable, land management strategy (LMS), included: society participation in choosing land management model (LMS1), supporting policy and stakeholders' function (LMS2), agricultural plants diversification (LMS3), and land using based on spatial plan (LMS4). The last variable, land degradation (LD), included: sedimentation level of river (LD1), soil fertility level (LD2), and lower agricultural crop (LD3).

\section{DISCUSSION}

Study of connection between socio-cultural behaviors and land degradation as a result of land-resource using viewed from social capital perspective was an important factor in land management system. Seriously declined land along with economic complexity faced by society seemed to be the provoking aspect in land management system. There was no doubt that society played primary role to decrease land degradation rate. However, at this time, programs applied in society were seemingly to discriminate their existence which surely was the main part in land management system.

Social system within society determin- ed land management system. Thesociety's socio-economic and cultural aspects were important in determining relation pattern among individuals and those with environment. Therefore, a perspective from social capital view is important to explain society's social changes in natural resource using (Setiahadi 2012). Finally, one of many social theories used to describe social actions and social relations in natural resource using and management was social capital concept.

Speaking about watershed management, land degradation happened in it is influenced by condition of social structure, economy, and culture. That is why, the overwhelming using of natural resources is a kind of nature exploitation causing land degradation. Land degradation of Tulis watershed was not only using the land practically, but also reflecting the socio-cultural aspect of watershed society. The society who performed agricultural cultivation was believed as the stimulus of land degradation. Consequently, social capital of the society contributed importantly to good land management. Presented in Figure 1 below is the relation model between social capital of Tulis watershed society and land degradation.

Figure 1 displayed causal relation among variables in structural model pre-

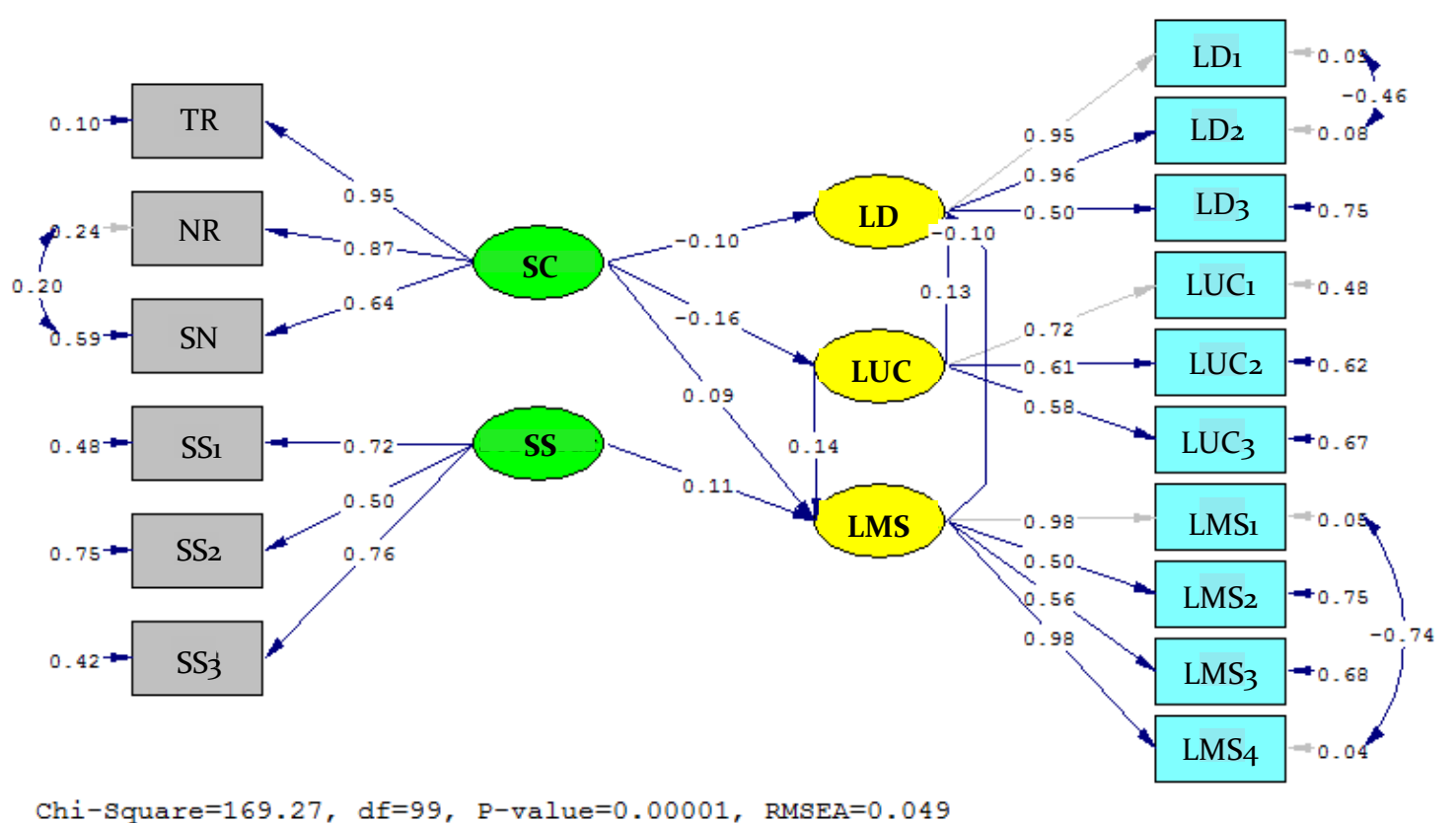

Fig. 1. Model of Relation between Social Capital and Land Degradation in Tulis Watershed. 
Table 1. Construction of Effects between Variables Model (Social Capital and Land Degradation in Tulis Watershed)

\begin{tabular}{|c|c|c|c|c|c|}
\hline \multirow{2}{*}{$\begin{array}{l}\text { Independent } \\
\text { Variables }\end{array}$} & \multirow{2}{*}{$\begin{array}{c}\text { Dependent } \\
\text { Variables }\end{array}$} & \multicolumn{4}{|c|}{ Influence } \\
\hline & & Direct & Indirect & Total & t-Value \\
\hline Social Capital & $\begin{array}{l}\text { Conflict of Interest in Land } \\
\text { Using }\end{array}$ & $-0,16$ & - & $-0,16$ & $-2,32$ \\
\hline Social Capital & Land Management Strategy & 0,09 & $-0,02$ & 0,07 & 1,63 \\
\hline Social Capital & Land Degradation & $-0,10$ & $-0,03$ & $-0,13$ & $-2,61$ \\
\hline Society Stucture & Land Management Strategy & 0,11 & - & 0,11 & 2,33 \\
\hline Society Stucture & Land Degradation & 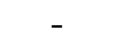 & $-0,01$ & $-0,01$ & $-1,63$ \\
\hline $\begin{array}{l}\text { Conflict of Interest in } \\
\text { Land Using }\end{array}$ & Land Management Strategy & 0,14 & - & 0,14 & 2,54 \\
\hline $\begin{array}{l}\text { Conflict of Interest in } \\
\text { Land Using }\end{array}$ & Land Degradation & 0,13 & $-0,01$ & 0,12 & 1,98 \\
\hline $\begin{array}{l}\text { Land Management } \\
\text { Strategy }\end{array}$ & Land Degradation & $-0,10$ & - & $-0,10$ & $-2,43$ \\
\hline
\end{tabular}

Source: Primary Data, constructed 2014

sented. A table was made to clarify the relation.

Figure 1 and Table 1 showed that social capital affected land degradation indirectly through conflict of interest cases in land using and strategy applied to land management. Social capital brought negative effect to conflict of interest cases in term of land using. The negative value means that strong social capital was potentially in declining conflict of interest.

On the other hands, social capital gave positive value to watershed land management strategy. It reveals that management strategy was worthwhile when it was supported by strong social capital. In addition, society structure also contributed positive effect to land management strategy. It shows that society structure helped much in choosing effective land management. Therefore, land management strategy is more meaningful in case of supports from strong social capital and strong society structure both socially and economically. Society with lower level of education and economic condition became the challenging problem in deciding appropriate land management strategy in Tulis watershed.

Moreover, Figure 1 and Table 1 indicated how conflict of interest in land using contributed the next land management strategy. The arising conflicts were about to increase the quality of management strategy choosing became more effective. However, bad management of conflict was the cause of increasingly land degradation. To anticipate, these conflicts of interest are controllable through effective land management. The effective and precise strategy is able to reduce conflict and potentially arising conflict so that it will lessen the land degradation frequency.

The preceding description illustrated that social capital, conflict, and society structure are the supporting elements how the effective watershed management strategy was chosen to overcome land degradation of Tulis watershed. Dynamic society structure strengthened by solid social capital and controlled conflict was able to define the effective management strategy in decreasing land degradation. Hence, hypothesis of the research, which society structure with strong social capital, low conflict of interest in land using, and effective land management strategy were able to reduce land degradation, was acceptable.

Land using as living source is the important component to society who live in Tulis watershed. The weak organizational system, the breaking of social norm in land management, such as eco-friendly land management regarding land and water conservation system, and the lower trust among society components caused progressively land degradation. 
Furthermore, inexistence of regulation strictly containing society's rights and tasks in land management due to preservation principles contributed to the higher land degradation of Tulis watershed. The other cause of enhanced land degradation was the norm breaking of social hierarchy. Coleman (1988) described that norms developing in society become rule of society behavior as the collective responsibility representation. The obeyed norms and rule influence to relieve natural and socio-cultural environment condition of society.

In tradition's point of view and historical habits, Koentjaraningrat (1994) stated that people learn from two kinds of relation, specifically, that between people and natural environment, and inter personal relation. Based on culture value orientation, Koentjaraningrat argued about how people assess the nature, 1) people conform to the nature, 2) people try to balance their life with the nature, and 3) people are obsessed to dominate the nature.

The basic problem in Tulis watershed land management was farmers' belief that their right in using land was a kind of land control. This belief, then, was underlying the farmers' individualistic behaviors. According to Hardin (1968), the condition makes the society thinks and acts to obtain as many advantages as they can from nature without anybody among them maintaining nature resource at advantageous level.

Land degradation in Tulis watershed lasted for a long time. People in Dieng Plateau have planted potato since 1970's. At these years, planting potato was done traditionally and intended to satisfy domestic need. As technology developed, in 1980's people in this area planted potato intensively (Sumedi 2010). Therefore, potato became the leading agricultural commodities. Society in Dieng started cultivating potato commercially that later caused society social order changed. The massive exploitation to land resource began which affected land degradation of the area.

As time went by, potato was no longer good agricultural commodities. Many farmers faced serious financial misfortune.
This condition was triggered by lessened soil fertility as land degradation of Tulis watershed increased. Farmers' awareness came up since benefit of potato yield was not enough to meet their daily needs. Nevertheless, there still were many farmers believed that potato, someday, turns to be promising agricultural commodities. Farmers with different point of view were intending a change, which is leading to their economy, social, and culture be better.

Harmonization between land management system and society needs for life became an important factor in sustainable natural resource using. Sustainable land management system promises better life to society of the area. Social capital of the society developed a basis in determining proper land management strategy. Trust between farmers and society leaders, applying soil and water conservation techniques as part of social norm, and developing non production sector along with strong networking of society organization are expected to lower land degradation level so sustainable land management is reached. In other words, exploring land resource, society of Tulis watershed should maintain it balanced. As conclusion, what happened in Tulis watershed is not exploiting natural resource, but adjusting the society to land using as production factor to increase farmers' wealth.

\section{CONCLUSION}

Perspective of social capital theory was applied to explain the relation between socio-cultural behavior of society and land degradation in land resource using of $\mathrm{Tu}-$ lis watershed. Social capital such as trust, norms, and social networking contributed in decreasing land degradation level through sustainable land resource management system. Society structure with strong social capital, low conflict of interest in land using, and supported by effective land management strategy were able to decrease land degradation.

\section{REFERENCES}

Aulia, A., 2011. Dampak Modal Sosial (Lengge) terhadap Peningkatan Pendapatan Masyarakat Tani 
(Studi Kasus pada Masyarakat "Lengge" di KabupatenBima). Thesis. Sekolah Pasca Sarjana, UniversitasGadjahMada. Yogyakarta.

Brondizio, E.S., Ostrom, E. and Young, O.R., 2009 Connectivity and the governance of multilevel social-ecological systems: the role of social capital. Annual review of environment and resources, 34, pp.253-278.

Budiono, H., 2010. Pengaruh Modal Sosial TerhadapKeberlanjutan Kelompok Tani Hutan Kemasyarakatan di Kabupaten Gunung Kidul. Tesis. Sekolah Pasca Sarjana, Universitas Gadjah Mada. Yogyakarta.

Budiono, R.P., 2006. Karakteristik Petani Tepi Hutan dan Kompetensinya dalam Melestarikan Hutan Lindung di 12 Desa di Provinsi Lampung. Disertasi. Sekolah PascaSarjana, Institut Pertanian Bogor. Bogor.

Chomitz, K.M. and A. Nelson., 2007. The Forest-Hydrology-Poverty Nexus in Central America: An Heuristic Analysis. Journal of Environment, Development, and Sustainability 9, pp.369-385.

Coleman, J.S., 1988. Social Capital in the Creation of Human Capital. The American Journal of Sociology. 94, pp.195-120.

Fukuyama, F., 1995. Trust: The Social Virtues and The Creation of Prosperity.The Free Press. New York. TerjemahanRuslani. 2007. Trust: KebajikanSosialdanPenciptaanKemakmuran. Cetakan II. Qalam. Yogyakarta.

Genskow, K.D. and Born, S.M., 2006. Organizational dynamics of watershed partnerships: a key to integrated water resources management. Journal of Contemporary Water Research E Education, 135(1), pp.56-64.

Handoyo, E., 2013. Kontribusi Modal Sosial dalam Meningkatkan Kesejahteraan Pedagang Kaki Lima Pasca Relokaksi. Jurnal Komunitas. 5(2), pp.252-266.

Hardin, G., 1968. Tragedy of the Common. Journal of Science, 162 (3859), pp.1243-1248

Indrawardana, I., 2012. Kearifan Lokal Adat Masyarakat Sunda dalam Hubungan dengan Lingkungan Alam. JurnalKomunitas, 4(1), pp.1-8.

Koehler, B. and Koontz, T.M., 2008. Citizen participation in collaborative watershed partnerships. Environmental management, 41(2), p.143.

Koentjaraningrat, 1994. Pengantar Antropologi. Gramedia. Jakarta.

Leahy, J.E. and Anderson, D.H., 2010. "Cooperation gets it done": social capital in natural resources management along the Kaskaskia River. Society and Natural Resources, 23(3), pp.224-239.

Mandarano, L., Meenar, M. and Steins, C., 2010. Building social capital in the digital age of civic engagement. CPL bibliography, 25(2), pp.123-135.

Mandarano, L.A., 2008. Evaluating collaborative environmental planning outputs and outcomes: restoring and protecting habitat and the New York-New Jersey harbor estuary program. Journal of planning education and research, 27(4), pp.456-468.

Mandarano, L.A., 2009. Social network analysis of so- cial capital in collaborative planning. Society and natural resources, 22(3), pp.245-26o.

Parkes, M.W., Morrison, K.E., Bunch, M.J., Hallström, L.K., Neudoerffer, R.C., Venema, H.D. and Waltner-Toews, D., 2010. Towards integrated governance for water, health and social-ecological systems: The watershed governance prism. Global Environmental Change, 20(4), pp.693-704.

Pretty, J. \& Ward, H., 20o1. Social Capital and The Environment. Paper Submitted to World Bank. Journal of world Development, 29(2), pp.209227.

Putnam, R, D., 200o. Bowling Alone The Collapse and Revival of American Community. Simon and Schuster, New York.

Rathwell, K.J. and Peterson, G.D., 2012. Connecting social networks with ecosystem services for watershed governance: a social ecological network perspective highlights the critical role of bridging organizations. Ecology $\mathcal{E}$ society, $17(2)$, p.24.

Sadeghi, S.H.R., Jalili, K. \& Nikkami, D., 2009. Land use optimization in watershed scale. Land Use Policy, 26(2), pp.186-193.

Saputra, A.M., 2010. Pengelolaan Hutan Bersama Masyarakat. Studi Modal Sosial dan Partisipasi Masyarakat dalam Program Pemberdayaan Masyarakat di Desa Karang Tengah Kecamatan Babakan-Medang Kabupaten Bogor. Tesis. Sekolah Pasca Sarjana, Universitas Gadjah Mada. Yogyakarta.

Setiahadi, R., 2012. Modal Sosial dalam Pembangunan Hutan: Penyelesaian Deforestasi dan KonflikSosial. Disertasi. Program Pasca Sarjana UniversitasGadjah Mada. Yogyakarta.

Suandi. 2014. Hubungan Modal Sosial dengan Kesejahteraan Ekonomi Keluarga di Daerah Perdesaan Jambi. Jurnal Komunitas, 6(1), pp.38-46.

Sumedi, N., 2010. Strategi Pengelolaan Wilayah Hutan Pegunungan: Studi Kasus Pegunungan Dieng Jawa Tengah. Disertasi. Program Studi Ilmu Kehutanan, Program Pasca Sarjana, FakultasKehutanan, Universitas Gadjah Mada. Yogyakarta.

Susilowati, R., 2007. Peran Modal Sosial dalam Pelaksanaan Program Hutan Kemasyarakatan (Studi Kasus di Kabupaten Gunung Kidul). Tesis. Sekolah Pasca Sarjana, Universitas Gadjah Mada. Yogyakarta.

United Nations Development Programmes, 2013. Summary Base Line Data DAS Tulis. Strengthening Community Based Forest and Watersher Management (SCBFWM). Region Yogyakarta.

Wagner, C.L. and Fernandez-Gimenez, M.E., 2008. Does community-based collaborative resource management increase social capital?. Society and Natural Resources, 21(4), pp.324-344.

Woolcock, M., 2001. The Place of Social Capital in Understanding Social and Economic Outcomes. Isuma: Canadian Journal of Policy Research, 2 (1), pp.1-7. 